\title{
Biotic and abiotic correlates of tissue quality for common scleractinian corals
}

\author{
M. O. Hoogenboom ${ }^{1, *}$, S. R. Connolly ${ }^{1,2}$, K. R. N. Anthony ${ }^{3}$ \\ ${ }^{1}$ ARC Centre of Excellence for Coral Reef Studies, James Cook University, Townsville, Queensland 4811, Australia \\ ${ }^{2}$ School of Marine and Tropical Biology, James Cook University, Townsville, Queensland 4811, Australia \\ ${ }^{3}$ ARC Centre of Excellence for Coral Reef Studies, and School of Biological Sciences, University of Queensland, \\ Brisbane 4072, Australia
}

\begin{abstract}
Reef-building corals provide critical ecosystem functions but are under pressure from a range of stressors, and there is a growing need to understand how environmental factors affect the physiological condition of corals. This study explored the relationships between tissue quality (i.e. energy content per unit surface area) and light intensity, water flow velocity, temperature, colony size and competition for 4 common coral species. A formal model selection procedure revealed that different corals, even species that are closely related and morphologically similar, respond to their local environments in fundamentally different ways. Overall, colony size was the most consistent predictor of tissue quality, and the observed increase in tissue energy content with size may partially explain field observations of reduced mortality for large colonies. However, competitive interactions, light intensity, water flow and temperature also contributed to variation in tissue properties. Warming reduced the tissue quality of massive and foliose corals more than that of branching corals, despite the latter generally being recognised as more susceptible to thermal bleaching. These findings identify species- and habitat-specific responses to baseline environmental variables that can be used to anticipate shifts in coral health under environmental change.
\end{abstract}

KEY WORDS: Light intensity - Water flow · Colony size - Temperature - Competition · Bioenergetics $\cdot$ Statistical modelling $\cdot$ Model-average regression coefficient

\section{INTRODUCTION}

Simple rules for translating environmental conditions into predictions of species distributions remain elusive. Over the coming years, the predicted increases in seawater temperature and changes in ocean chemistry associated with increasing atmospheric $\mathrm{CO}_{2}$ concentrations mean that many species will be confronted with conditions that lie outside of their tolerance ranges (Chown \& Gaston 2008, Farrell 2009). Environmental conditions, such as light and temperature, primarily affect organisms through physiological processes. For example, light intensity influences rates of photosynthesis of plants and algae
(Falkowski \& Raven 2007) and temperature affects metabolic rates (Gillooly et al. 2001). Correspondingly, predictions of how a species' distribution will change in the future require a mechanistic understanding of the links between environmental conditions and organism physiology.

Coral reefs are iconic ecosystems that are particularly sensitive to climate change. Excessive temperature causes a breakdown of coral-algal symbioses ('coral bleaching', Hoegh-Guldberg 1999) and decreases the amount of energy available for coral growth and survival (e.g. Weis \& Allemand 2009, Anthony et al. 2009). Although threshold temperatures for coral bleaching are now reasonably well 
characterized (e.g. Berkelmans 2002, McClanahan et al. 2007), variation in the energy balance of coral colonies across the natural range of environmental temperatures (not just the extremes) has been poorly studied. Moreover, potential synergies between temperature and other environmental variables, such as light intensity and water flow velocity, have rarely been investigated because most studies quantify the effects of only 1 or 2 environmental variables and only at specific levels (e.g. Ward 1995, Edmunds 2005, Hoogenboom et al. 2006). Correspondingly, the literature identifies several variables that influence the physiology of particular coral species but does not detect which variable has the strongest impact, or whether the dominant variable is consistent among species.

Over the past 3 decades, several studies have investigated how the biotic and abiotic environments influence coral ecology. However, such studies have typically focused on identifying drivers of community composition (Done 1982, DeVantier et al. 2006), or environmental correlates of colony growth rates (e.g. Hubbard \& Scaturo 1985, Villinski 2003). In addition to changes in skeletal growth, tissue thickness and composition also vary in response to environmental conditions (e.g. Anthony et al. 2002, Oku et al. 2003). Quantifying tissue characteristics is important because high biomass and/or lipid stores can mitigate the effects of various environmental stressors (Rinkevich 1996). Indeed, in a recent study, we showed that increased lipid stores prior to the onset of bleaching enhanced survival of coral colonies (Anthony et al. 2009). Therefore, understanding the factors that influence tissue properties allows a better understanding of the conditions under which mortality risk may be elevated. In essence, tissue quality indicates the resources that corals have on hand to deal with current environmental stressors whereas measurements of growth rate indicate how past environmental conditions (i.e. during the time period over which measurements were made) affected energy allocation to growth alone.

In addition to physical gradients, biotic factors can influence tissue properties. First, colony size influences coral energy balance with rates of metabolism (Jokiel \& Morrisey 1986) and particle capture scaling non-linearly with colony size (Kim \& Lasker 1998). In addition, there can be strong competition for space within reef environments (e.g. Jackson 1977) and inter-specific interactions can result in mortality due to overgrowth (Baird \& Hughes 2000), or digestion by the tentacles of neighbouring colonies (Lapid \& Chadwick 2006). Competition also has sub-lethal effects, causing a reduction in coral growth rates and reproductive output (Rinkevich \& Loya 1985). Clearly, competition potentially has a negative impact on tissue quality but it is not known how strong these effects are relative to environmental gradients of light, temperature and water flow.

Given that a number of current threats to coral reefs affect physiological condition directly (e.g. thermal anomalies, ocean acidification, turbidity), it is increasingly important that the key determinants of coral physiological health are identified. Using tissue energy content (measured from protein and lipid composition) as a proxy for coral health, this study aimed to identify the principal correlates of variation in tissue quality in response to environmental conditions, and in response to differences in colony size and competition intensity. An additional aim of this work was to determine how the relative importance of these factors varied between 4 coral species that are common in a range of habitats. To achieve these aims, tissue quality of Acropora nasuta, A. millepora, Leptoria phrygia and Montipora foliosa/aequituberculata (hereafter Montipora) was measured at sites with varying light, flow and temperature conditions.

Table 1. Light, temperature and water flow conditions observed at study sites at Orpheus and Pelorus Islands (OP) and One Tree Island (OTI). Light data are mean daily maximum irradiances, temperature data are averages of measurements taken at $15 \mathrm{~min}$ intervals, and flow data represent average daily water movement. Depths are shown relative to lowest astronomical tide (LAT), except for lagoon sites at OTI, marked with an asterisk, which are given relative to low tide (because OTI has a ponding lagoon). Standard errors are shown in parentheses, nd denotes no data. See Fig. 1 for site abbreviations

\begin{tabular}{|lcccc|}
\hline Site & $\begin{array}{c}\text { Depth Light }(\mu \mathrm{mol} \\
(\mathrm{m}, \mathrm{LAT})\end{array}$ & $\begin{array}{c}\text { Temp. } \\
\text { photons } \\
\left.\mathrm{m}^{-2} \mathrm{~s}^{-1}\right)\end{array}$ & $\begin{array}{c}\text { Water } \\
\text { flow } \\
\left(\mathrm{Cm} \mathrm{s}^{-1}\right)\end{array}$ \\
\hline NP - OP & 2.6 & $1300(117)$ & $30.4(0.02)$ & nd \\
SEP - OP & 1.6 & $949(76)$ & $29.6(0.01)$ & nd \\
EO - OP & 3.1 & $870(66)$ & $29.2(0.02)$ & nd \\
SWP - OP & 1.7 & $1463(98)$ & $30.1(0.03)$ & nd \\
CB - OP & 1.7 & $1324(102)$ & $29.7(0.03)$ & nd \\
PB - OP & 1.3 & $1381(103)$ & $29.3(0.03)$ & nd \\
L 3 - OTI & $0.6 *$ & $1358(115)$ & $25.5(0.04)$ & $5.6(0.8)$ \\
L 1 - OTI & $0.5^{*}$ & $1556(133)$ & $25.8(0.04)$ & $6.6(0.9)$ \\
L 2 - OTI & $0.6^{*}$ & $1501(65)$ & $26.1(0.04)$ & $13.1(1.4)$ \\
S 1 - OTI & 4.4 & $983(42)$ & $25.4(0.01)$ & $16.6(1.7)$ \\
S 2 - OTI & 4.3 & $1099(52)$ & $24.4(0.02)$ & $30.3(2.9)$ \\
S 3 - OTI & 3.8 & $1024(60)$ & $25.3(0.03)$ & $25.3(3.1)$ \\
S 4 - OTI & 2.6 & $1174(54)$ & $25.5(0.04)$ & $22.9(3.0)$ \\
D 1 - OTI & 9.7 & $578(18)$ & $24.2(0.01)$ & $12.0(1.5)$ \\
D 2 - OTI & 7.5 & $684(33)$ & $24.4(0.01)$ & $18.0(1.8)$ \\
D 3 - OTI & 7.4 & $664(47)$ & $24.6(0.01)$ & $18.8(2.2)$ \\
\hline
\end{tabular}


We then modelled the effect on tissue quality of these environmental variables, along with colony size and competition intensity, to estimate the magnitude of, and assess the strength of evidence for, each of these hypothesized predictors' effects on tissue quality for each species.

\section{MATERIALS AND METHODS}

\section{Fieldwork and study species}

Fieldwork was conducted between June and December 2005 at Orpheus and Pelorus Islands (OP), and between November 2005 and November 2006 at One Tree Island (OTI, Great Barrier Reef, Australia). Environmental conditions were monitored at 6 sites at OP and at 10 sites within and around OTI lagoon, with sites stratified to encompass a range of light, temperature and flow conditions (Table 1, Fig. 1). These environmental variables were selected because they are known to strongly affect multiple aspects of coral biology including photosynthesis rates, bleaching severity, food capture and growth (Chalker et al. 1983, Lesser et al. 1994, Sebens et al. 2003, Edmunds 2005), and thereby influence colony energy balance and tissue properties. Indeed, a recent study has demonstrated a strong correlation between energy balance (photosynthesis minus respiration) and 2 components of tissue quality (protein content and reproductive output, Hoogenboom \& Connolly 2009). Sites were established as semipermanent transects along depth contours (dimensions $30 \mathrm{~m}$ long and $4 \mathrm{~m}$ wide), and were marked with pickets hammered into the substratum. At each site, light and temperature profiles were measured using Odyssey loggers (Dataflow Systems). At OP, light and temperature were measured at various times during 2005: between 8 and 12 June, between 10 and 16 October, and between 27 November and 8 December. At OTI, the same measurements were made between 6 and 17 November 2005, and from 28 May to 18 June and 7 to 15 November in 2006. At OTI, water flow measurements were made simultaneously at all sites over a period of $10 \mathrm{~d}$ during November 2006, and additionally during May and June 2006 at sites within the lagoon. Flow (convection) was estimated using a plaster dissolution technique (Fulton \& Bellwood 2005). During each of 5 deployments, 3 replicate gypsum balls $(6 \mathrm{~cm}$ diameter) were affixed to individual pickets $15 \mathrm{~cm}$ above the substratum at each site. The rank order of study sites, based on light, flow and temperature con- ditions, was generally consistent throughout the measuring period (Table $\mathrm{S} 1$ in the supplement at www.int-res.com/articles/suppl/m438p119_supp.pdf). There were no obvious differences in the abundance of coral predators between sites at either of One Tree Island or Orpheus and Pelorus Islands.

Within each site, fragments of Acropora millepora (family Acroporidae) were collected at OP in October 2006, and of A. nasuta (family Acroporidae), Leptoria phrygia (family Faviidae) and Montipora foliosal aequituberculata (family Acroporidae) at OTI during November 2006. Colonies were selected to represent a range of sizes but were otherwise sampled as encountered along transects. We did not distinguish between the 2 Montipora species because correct identification is based on the prevalence of skeletal ridges that are not always obvious in the field (Veron 2000). Collection was made prior to coral spawning at each location on the basis that energetic content of tissue is maximal at this time due to the accumulation of lipids (Leuzinger et al. 2003). At OP, 10 colonies

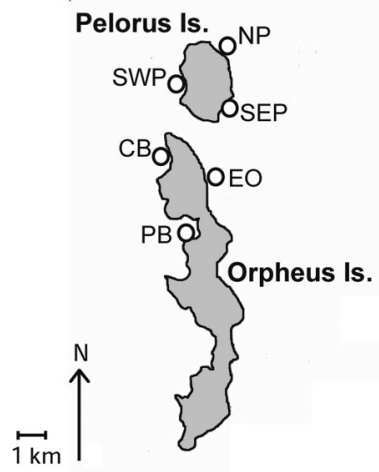

$$
\begin{aligned}
& \text { ORPHEUS \& PELORUS } \\
& \text { Site details } \\
& \text { PB - Pioneer Bay } \\
& \text { (146.28.962E, 18.36.744S) } \\
& \text { CB - Cattle Bay } \\
& \text { (146.29.039E, 18.34.496S) } \\
& \text { SWP - Southwest Pelorus } \\
& \text { (146.29.299E, 18.33.029S) } \\
& \text { EO - East Orpheus } \\
& \text { (146.29.850E, 18.35.397S) } \\
& \text { SEP - Southeast Pelorus } \\
& \text { (146.30.103E, 18.33.602S) } \\
& \text { NP - North Pelorus } \\
& \text { (146.29.922E, 18.32.370S) }
\end{aligned}
$$

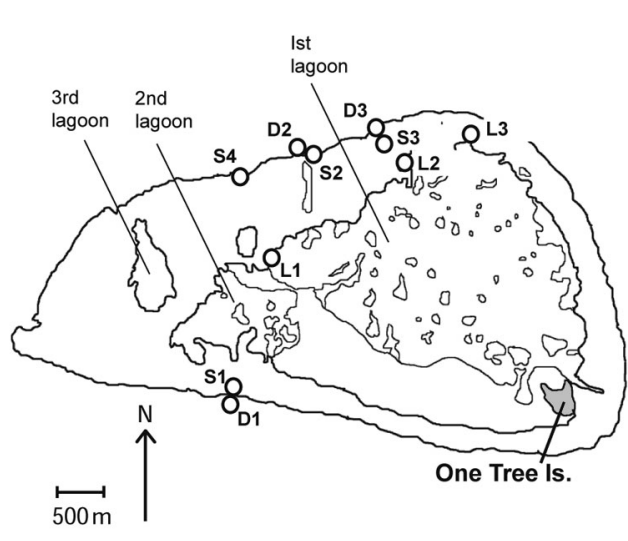

ONE TREE ISLAND Site details D1, S1 - Wisteria (23.30.511S, 152.03.372E) L1 - Lagoon wall (23.29.793S, 152.03.821E) L2 - Lagoon entrance (23.29.221S, 152.04.612E) L3 - Northeast lagoon (23.29.118S, 152.04.874E) S2 - Long bank (23.29.163S, 152.04.036E) D2 - Long bank (23.29.149S, 152.04.027E) S3, D3 - Entrance (23.28.961S, 152.04.512E) S4 - Daves notch (23.29.333S, 152.03.634E)

Fig. 1. Locations of study sites at Orpheus and Pelorus Islands (Palm Island Group, Queensland, Australia) and at One Tree Island (Capricorn Bunker Group, Queensland, Australia). Latitude and longitude of each site are given in parentheses 
were sampled per site during October 2005, and at OTI, 6 colonies of each species were sampled from 9 sites (at 1 site only Montipora was present, and this species was absent from 1 other site). Four fragments (diameter 3 to $4 \mathrm{~cm}$ ) were collected from all colonies and frozen at $-20^{\circ} \mathrm{C}$ prior to analysis.

\section{Tissue quality, colony size and competition intensity}

Tissue quality was measured as the sum of total protein and lipid content per unit surface area, with quantities of both measures converted to energetic equivalents based on enthalpies of combustion (Gnaiger 1983, $23.9 \mathrm{~J} \mathrm{mg}^{-1}$ for protein and $39.5 \mathrm{~J}$ $\mathrm{mg}^{-1}$ for lipid, see Anthony \& Fabricius 2000). Carbohydrates were excluded because they generally contribute only a small proportion of tissue biomass ( $<10 \%$ for 8 coral species, Leuzinger et al. 2003). Total protein was measured using a Bio-Rad total protein kit and protocol (Bio-Rad Laboratories). To do this, standards of known protein concentration between 0 and $2 \mathrm{mg} \mathrm{ml}^{-1}$ were prepared using bovine serum albumen (BSA, Sigma Chemicals). Tissue from each fragment (2 per colony) was then solubilized during 2 successive $1 \mathrm{~h}$ digestions in $1 \mathrm{M}$ $\mathrm{NaOH}$ at $90^{\circ} \mathrm{C}$. Subsequently, $100 \mu \mathrm{l}$ of protein extract was combined with $5 \mathrm{ml}$ of reagent and absorbance at $595 \mathrm{~nm}$ was measured spectrophotometrically. Total protein content of samples was determined by comparison to the absorbance of the calibration standards and averaged $1.5 \mathrm{mg} \mathrm{cm}^{-2}$ (range 0.7 to 2.2) for Acropora millepora; $1.5 \mathrm{mg} \mathrm{cm}^{-2}$ (range 0.7 to 2.6 ) for $A$. nasuta; $2.7 \mathrm{mg} \mathrm{cm}^{-2}$ (range 1.2 to 4.6 ) for Leptoria phrygia; and $2.6 \mathrm{mg} \mathrm{cm}^{-2}$ (range 1.2 to 4.4) for Montipora. Lipid content was determined gravimetrically following the procedure described by Leuzinger et al. (2003). Briefly, fragments ( 2 per colony) were ground into a fine paste, lipids were extracted in a chloroform-methanol solution $(2: 1, \mathrm{v} / \mathrm{v})$, and lipid weight was obtained following separation and evaporation of chloroform. Protein and lipid were normalized to surface area that was measured using the foil-wrapping method (Marsh 1970). Total lipid content averaged $1.5 \mathrm{mg} \mathrm{cm}^{-2}$ (range 0.8 to 3.9) for A. millepora; $2.0 \mathrm{mg} \mathrm{cm}^{-2}$ (range 0.8 to 6.3 ) for $A$. nasuta; $10.3 \mathrm{mg} \mathrm{cm}^{-2}$ (range 4.5 to 21.2 ) for L. phrygia; and $6.3 \mathrm{mg} \mathrm{cm}^{-2}$ (range 1.5 to 12.8) for Montipora.

Immediately prior to fragment collection, all of the colonies were photographed in the field using a ruler as a scale bar. Colony size and competition were determined by image analysis (ImageTool, UTHSCSA). Colony size was measured as the average of the longest colony diameter and the diameter perpendicular to this. Competition was estimated based on the extent of 'crowding', calculated from the proportion of the colony circumference that was in direct contact with, or being overtopped by, a competitor. All potential competitors were recorded, including macroalgae, soft corals and other scleractinians, if their height was at least equal to that of the sampled colony. For example, if an encrusting colony extended underneath a branching colony this was only counted as a competitive interaction for the encrusting colony.

\section{Data analysis}

Prior to analysis, each variable was standardised to have a mean of zero and a standard deviation of 1 . Standardisation puts all predictors on a common scale and makes regression coefficients comparable as estimates of the strength of effects of alternative explanatory variables (Zar 1999). To determine the contribution of each predictor to variation in tissue quality, a set of multiple regression models, representing all possible combinations of our explanatory variables, were fitted to data for each species, and the fit of each of these models was compared. Models were fitted to data using standard least-squares methods, and thus Akaike's Information Criterion (AIC) for each potential model, $i$, was calculated as (Burnham \& Anderson 2002):

$$
\mathrm{AIC}_{i}=n \log \left(\frac{\mathrm{SSE}}{n}\right)+2(j+1)
$$

where $n$ is the number of data points the model was fitted to, SSE is the sum of squared errors of the fitted model and $j$ is the number of fitted parameters in the model (i.e. intercept and slope parameters). Subsequently, the Akaike weight for each model $\left(w \mathrm{AIC}_{i}\right)$ is calculated as (Burnham \& Anderson 2002):

$$
{ }_{W A I C}=\exp \left(-\frac{\Delta \mathrm{AIC}_{i}}{2}\right)
$$

where $\Delta \mathrm{AIC}_{i}$ is the difference between the AIC value of model $i$ and the minimum AIC value of all models in the set; $W \mathrm{AIC}_{i}$ estimates the probability that model $i$ is the best in the set of $M$ models.

In this study, we wished to assess the overall strength of evidence for each of our putative predictor variables, across the entire set of candidate models. To do this, $W^{A I C} C_{i}$ values were summed over all 
models that contained each specific predictor variable, $j$, as:

$$
w \mathrm{AIC}_{j}=\sum_{i=1}^{M} w \operatorname{AIC}_{i}(j)
$$

That is, the support for a given predictor variable, $j(w \mathrm{AIC})$, is the sum of the Akaike weights over all models that contain that predictor variable.

Where there are a large number of closely related models, such as in the present study, estimates of which model is the 'best' is subject to uncertainty, just as estimating the best-fit value of a parameter is subject to uncertainty (Burnham \& Anderson 2002). When this uncertainty is large, estimating the effect of a particular variable is more robust when it takes account of this model-selection uncertainty than when it is simply based on a single, estimated best model. This robust estimation can be done by 'model averaging' the regression parameters. That is, the estimated effect of a particular predictor variable, $\bar{\beta}_{j}$, is a weighted average over the subset of the candidate models that contain the variable $j$, where each model's parameter estimate is weighted according to the relative support for the inclusion of that variable (the ${ } \mathrm{AIC}_{j}$ value):

$$
\bar{\beta}_{j}=\frac{\sum_{i=1}^{M} w \mathrm{AIC}_{i} I_{j} \beta_{j i}}{w \mathrm{AIC}_{j}}
$$

where ${ }^{\prime} \mathrm{AIC}_{i}$ is as defined above, $\beta_{j i}$ is the regression coefficient for variable $j$ in model $i$ and $I_{j}$ denotes whether variable $j$ occurs in model $i$, and is equal to:

$$
I_{j}= \begin{cases}1 & \text { if predictor } j \text { is in model } i \\ 0 & \text { otherwise }\end{cases}
$$

To summarise, in this study the relative support for each variable as a predictor of tissue quality for each species was determined based on $\mathrm{WAIC}_{j \text {, }}$ and the direction and magnitude of the effect of each variable was based on $\bar{\beta}_{j}$. The primary aim of this study was to detect which among the set of abiotic and biotic variables were the strongest determinants of tissue quality for different coral species. Correspondingly, we specifically included quantitative variables in the analyses (e.g. light intensity, flow velocity) in place of variables (e.g. depth or reef zone) for which environmental variation could not be specified. The analyses presented here are robust to co-variation (Table S2 in the supplement at www.int-res.com/ articles/suppl/m438p119_supp.pdf) between explanatory variables. Multi-collinearity can cause changes in the magnitude and direction of regression coefficients of particular explanatory variables when co- varying variables are included or removed from the model (Zar 1999). The modelaveraging procedure applied here quantifies the magnitude of the regression coefficient for each variable in the presence and absence of all other variables (Burnham \& Anderson 2002). Strong multicollinearity would result in model-averaged regression coefficients that are not significantly different from zero for explanatory variables that do not have an independent effect on the response variable.

\section{RESULTS AND DISCUSSION}

This study simultaneously compared the effects of multiple abiotic and biotic factors on tissue quality of several coral species and has demonstrated that environmental conditions differentially influence tissue quality of different species (Fig. 2). As is typically the case when formal model selection techniques are applied to a large set of alternative models, there was a moderately high degree of model selection uncertainty: some models fit the data poorly, and had very low support (wAIC < 0.01), but several models had comparable levels of support (see Table S3 in the supplement at www.int-res.com/articles/suppl/ m438p119_supp.pdf). However, in contrast to the small differences between regression models, there was a clear differentiation between the relative support for each variable as a predictor of tissue quality for 3 of the 4 species (Fig. 2). Colony size and competition were the most strongly supported predictors for Acropora millepora and Montipora, and flow the best-supported predictor for Leptoria phrygia, whereas all predictors had approximately equal support for A. nasuta. Although these results provide physiological insight into species' niche differences, this study indicates that general patterns of species responses to environmental change are likely to be elusive, and that species composition is likely to be an important determinant of the responses of coral communities. This interpretation is generally consistent with studies on other taxa showing that the characteristics of species present within an ecosystem are at least as important as species diversity in determining ecosystem properties like total productivity and nutrient cycling (Hooper \& Vitousek 1997).

Of the variables investigated, colony size had the most consistent effect across species with tissue energy content always increasing with colony diameter (Figs. 2 \& 3). Model-averaged regression coefficient values for this variable were significantly greater than zero for each of the study species (Fig. 3, 
the $95 \%$ confidence intervals do not include zero for this predictor). Consistent with these findings, recent studies have demonstrated positive relationships between colony size and total energy acquisition for corals (Elahi \& Edmunds 2007, Hoogenboom \& Connolly 2009), and this process potentially drives the increase in tissue quality with colony size observed here. Overall, our results suggest that larger colonies, that have higher tissue energy content, are better able to withstand periods of stress. In particular, a tendency for tissue quality to increase
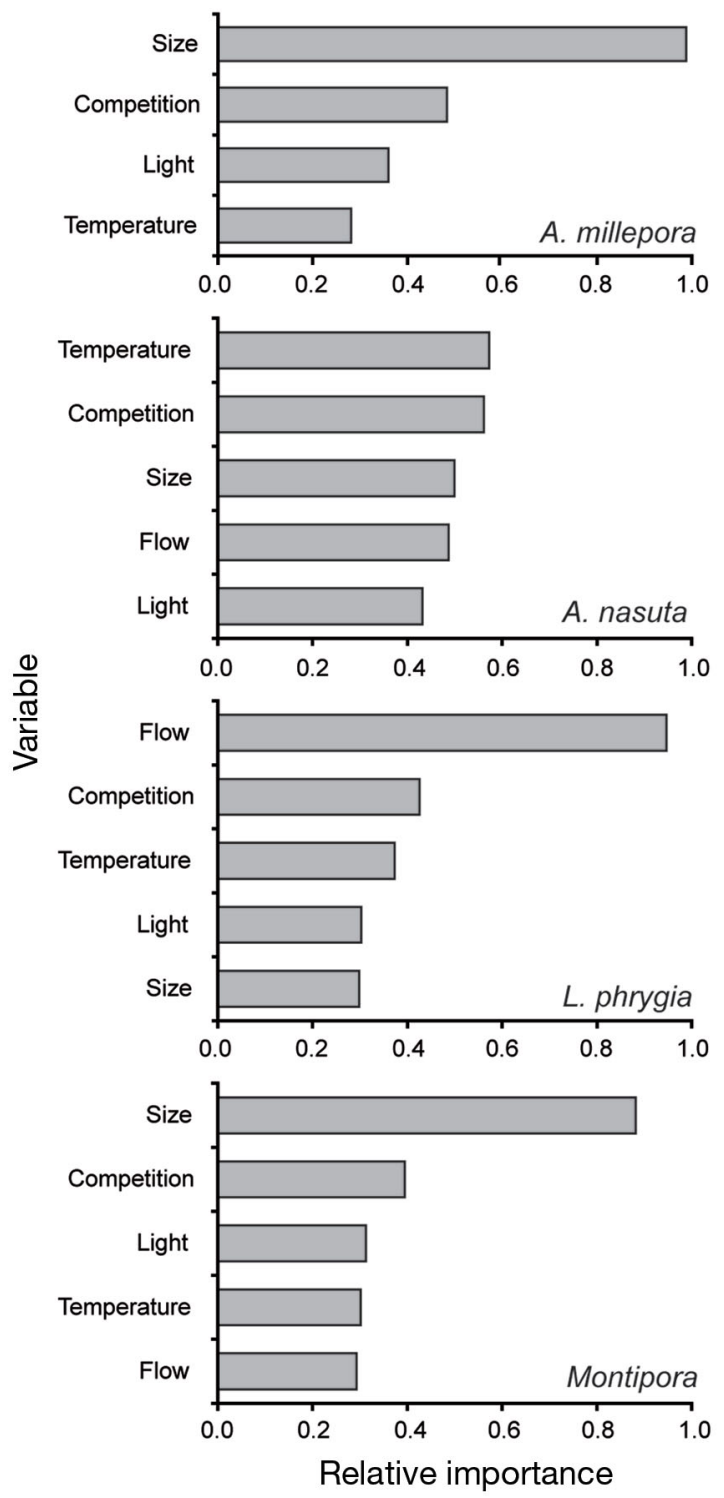

Fig. 2. Acropora millepora, A. nasuta, Leptoria phrygia and Montipora foliosa/aequituberculata. Relative importance of different predictors of tissue quality. Variable importance is calculated as the sum of Akaike weights over all candidate models that included each predictor with colony size is likely to at least partially explain the lower mortality rates typically reported for larger colonies in size-structured demographic studies (Babcock 1991, Tanner 2001, Edmunds 2010). More
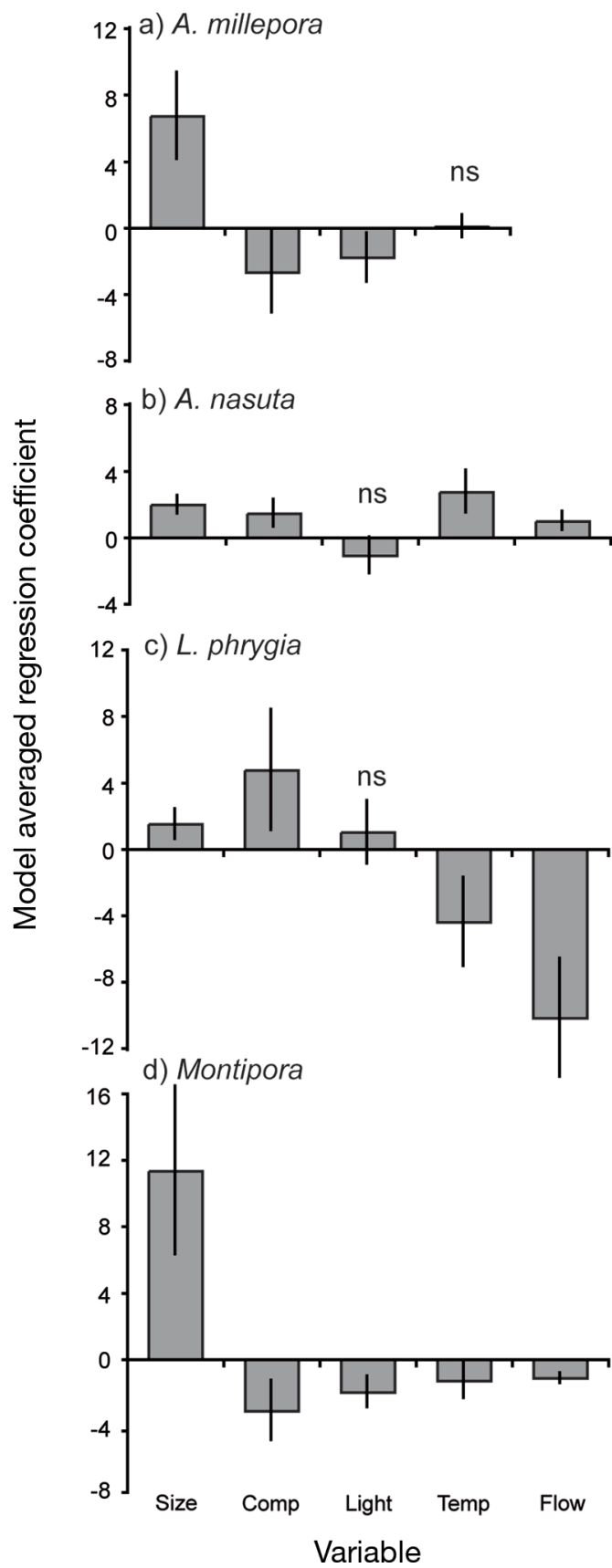

Fig. 3. Acropora millepora, A. nasuta, Leptoria phrygia and Montipora foliosa/aequituberculata. Model-averaged regression coefficients showing the effect of each predictor variable on tissue quality. To facilitate comparisons between species, the $y$-axis scale of each panel is equal although the panels are of different sizes. Error bars show $95 \%$ confidence intervals and ns denotes effects that are not significantly different from zero. Comp: competition; temp: temperature 
broadly, these findings indicate that environmental change might lead to a skew in coral colony sizefrequency distributions towards larger colonies. Although size distributions are undoubtedly influenced by recruitment processes, support for this prediction comes from studies in the Caribbean where an increase in the relative abundance of large compared to small coral colonies was observed on degraded reefs (Bak \& Meesters 1998).

Competition was consistently correlated with tissue quality (model average regression slopes for this variable were different than zero) for the study species but the direction of this effect was not consistent (Fig. 3). Nevertheless, the analyses indicated that Acropora millepora and Montipora were negatively influenced by the presence of competitors but that both A. nasuta and Leptoria phrygia had greater tissue quality when crowding intensity was high (Fig. 3). At present, there is no definitive explanation for the among-species differences in the observed competition responses. The negative effect of competition on tissue quality of Montipora is consistent with our expectations: of the 4 study species, Montipora was considered the most likely to be negatively impacted by competition because its growth form makes it susceptible to 'overtopping' (e.g. Baird \& Hughes 2000). For A. millepora, the negative effect of competition is potentially related to the greater intensity of competition with soft corals at OP compared with OTI (Fig. 4). Proximity to soft corals can cause tissue necrosis in scleractinian corals even when colonies are not in direct contact (Sammarco et

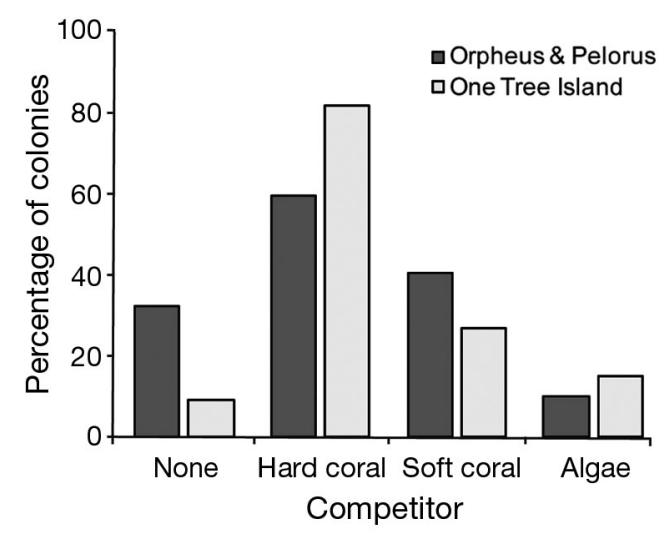

Fig. 4. Interactions between corals and different groups of competitors at Orpheus and Pelorus Islands (dark shaded bars) and at One Tree Island (light shaded bars). Values are the percentage of colonies observed in close proximity to either no competitors, other hard corals, soft corals or macroalgae. Data are pooled across sites at each location, and also pooled across species at One Tree Island al. 1985), and such interactions were almost 2-fold more frequent at OP than at OTI (Fig 4). Of the colonies that were directly involved in competition (i.e. excluding colonies in the 'None' category in Fig 4), $60 \%$ were in contact with soft corals at OP compared to $30 \%$ at OTI. At our study sites, interactions between corals and macroalgae were generally rare ( $<15 \%$ of colonies, Fig 4$)$. For the other 2 species, we propose that the positive relationship between tissue properties and competition intensity could be related to the fact that proximity to other colonies may suppress expansion over the substratum such that energy surpluses normally allocated to skeletal growth might instead be diverted into enhancing tissue growth and/or tissue quality (e.g. Anthony et al. 2002). Overall, these results indicate that the physiological health of coral colonies is not necessarily compromised by competitive interactions in high-density coral communities, and suggest that competition for space may influence energetic tradeoffs associated with reductions in colony growth. Clearly, however, the context- and species-specific nature of responses to crowding highlight the need for an improved understanding of the role of competition for space on physiological health.

The environmental variables (flow, light and temperature) affected the study species differently, both in terms of effect strength and magnitude (Figs. 2 \& $3)$. Water flow velocity was a strong predictor of tissue quality for the 3 species at OTI (flow data were unavailable for Acropora millepora), with a positive effect for A. nasuta and a negative effect for Leptoria phrygia and Montipora. Several studies have highlighted the importance of water flow in ameliorating stressors such as coral bleaching (e.g. Nakamura \& van Woesik 2001) and enhancing rates of photosynthesis (Rex et al. 1995, Hoogenboom \& Connolly 2009). These studies suggest a positive influence of flow on tissue quality, as also observed for A. nasuta in the present study. For Montipora, a negative relationship between flow and tissue quality is not unexpected: this genus is characteristic of 'sheltered' habitats (Done 1982) and is commonly found in reef caves and crevices where water flow velocity is low (e.g. Anthony \& Hoegh-Guldberg 2003). It is also possible that Montipora does poorly at high flow velocities because other species that are superior competitors benefit from increased flow. However, the very strong negative relationship between tissue quality and flow observed for $L$. phrygia is surprising. We propose that, rather than being negatively affected by high flow, this species may instead benefit from enhanced availability of heterotrophic food 
sources under low flow conditions. In this study, the lowest flow speeds occurred in the lagoon at OTI, and lagoonal waters tend to have higher particulate organic matter content than oceanic waters (e.g. Charpy et al. 1997). Since other massive corals have a high capacity for heterotrophic feeding (e.g. Anthony \& Fabricius 2000), greater food availability at low flow may explain this result for $L$. phrygia.

Light intensity and temperature also varied in the strength and direction of their effects on tissue quality (Fig. 2). In a previous study on the mound-shaped coral Goniastrea aspera, Oku et al. (2003) showed a positive relationship between light and temperature and tissue quality (measured as lipid content) over a seasonal cycle. In this study, temperature had a strong effect on tissue quality for all of the study species except for Acropora millepora, with the direction of this effect being positive for $A$. nasuta but negative for Leptoria phrygia and Montipora. Light intensity only had a significant effect on A. millepora and Montipora, and in both cases tissue quality tended to decline as light intensity increased. Although initially surprising, this negative effect is consistent with other research demonstrating a decrease in net energy acquisition of corals in high-light environments (Hoogenboom et al. 2009). Further support for the absence of a general positive relationship between light intensity and tissue quality comes from a study of 2 coral species on the Great Barrier Reef, for which tissue lipid content was lower on offshore reefs (with high light intensity) compared to coastal reefs (with low light intensity, Anthony 2006).

Although these results indicate that a single primary environmental driver of coral health is unlikely to exist, our findings suggest testable predictions about how the relative abundance of our study species may change as a function of environmental conditions. Contrary to our expectations of the temperature sensitivity of different coral species based on their susceptibility to thermal bleaching, our results indicate that tissue quality of Leptoria phrygia is negatively related to environmental temperature compared to the positive or neutral relationship observed for the 2 Acropora species. Branching and plateforming corals, like Acropora and Montipora, typically suffer high mortality following coral bleaching events (Marshall \& Baird 2000, Loya et al. 2001). Our study indicates that species that are relatively bleaching-tolerant, like L. phrygia, can in fact suffer negative effects from increasing environmental temperatures independently of observable effects of the symbiosis. Further support for this finding comes from recent observations of reduced growth rates of
A. millepora following heat stress, irrespective of whether colonies harboured heat-tolerant or heatsensitive symbionts (Jones \& Berkelmans 2010).

This study shows how the physiological condition of different coral species varies across multivariate environmental gradients. Advancing knowledge of the association between environmental conditions, physiological indicators of coral health and the relative abundance of coral species in different habitats is critical for the development of predictive models of changes in coral communities under different climate scenarios. Colony size was the only consistent predictor of tissue quality for the species considered here, with the effects of all other variables differing between species in direction and magnitude. Our findings indicate that changes to the total abundance and community structure of corals on reefs under climate change scenarios are likely to depend on which species are present, and on the size-frequency distribution of coral colonies. While descriptive modelling approaches, such as the regressions used here, can be used to detect how species' responses to environmental variables differ, a process-based modelling framework is likely to be needed to explicitly link species physiology to ecology. Such a framework could ultimately provide a foundation for predicting how inter-specific differences in organism responses to environmental change will influence the dynamics and structure of ecological communities.

Acknowledgements. We thank C. Glasson, M. Magnusson, J. Donelson and K. Johns for assistance with fieldwork and staff at One Tree Island and Orpheus Island research stations. This work was funded by the Australian Research Council, James Cook University and the Australian Coral Reef Society.

\section{LITERATURE CITED}

Anthony KRN (2006) Enhanced energy status of corals on coastal, high-turbidity reefs. Mar Ecol Prog Ser 319: $111-116$

Anthony KRN, Fabricius KE (2000) Shifting roles of heterotrophy and autotrophy in coral energetics under varying turbidity. J Exp Mar Biol Ecol 252:221-253

Anthony KRN, Hoegh-Guldberg O (2003) Variation in coral photosynthesis, respiration and growth characteristics in contrasting light microhabitats: an analogue to plants in forest gaps and understoreys? Funct Ecol 17:246-259

Anthony KRN, Connolly S, Willis BL (2002) Comparative analysis of energy allocation to tissue and skeletal growth in corals. Limnol Oceanogr 47:1417-1429

Anthony KRN, Hoogenboom MO, Maynard JA, Grottoli AG, Middlebrook R (2009) Energetics approach to predicting mortality risk from environmental stress: a case study of coral bleaching. Funct Ecol 23:539-550

Babcock RC (1991) Comparative demography of three 
species of scleractinian corals using age- and sizedependent classifications. Ecol Monogr 61:225-244

Baird AH, Hughes TP (2000) Competitive dominance by tabular corals: an experimental analysis of recruitment and survival of understorey assemblages. J Exp Mar Biol Ecol 251:117-132

> Bak RPM, Meesters EH (1998) Coral population structure: the hidden information of colony size-frequency distributions. Mar Ecol Prog Ser 162:301-306

> Berkelmans R (2002) Time-integrated thermal bleaching thresholds of reefs and their variation on the Great Barrier Reef. Mar Ecol Prog Ser 229:73-82

Burnham KP, Anderson DR (2002) Model selection and inference: a practical information theoretic approach, 2nd edn. Springer-Verlag, New York, NY

> Chalker BE, Dunlap WC, Oliver JK (1983) Bathymetric adaptations of reef-building corals at Davies reef, GBR, Australia. II. Light saturation curves for photosynthesis and respiration. J Exp Mar Biol Ecol 73:37-56

> Charpy L, Dufour P, Garcia N (1997) Particulate organic matter in sixteen Tuamotu atoll lagoons (French Polynesia). Mar Ecol Prog Ser 151:55-65

> Chown SL, Gaston KJ (2008) Macrophysiology for a changing world. Proc Biol Sci 275:1469-1478

$>$ DeVantier LM, De'Ath G, Turak E, Done TJ, Fabricius KE (2006) Species richness and community structure of reefbuilding corals on the nearshore Great Barrier Reef. Coral Reefs 25:329-340

- Done T (1982) Patterns in the distribution of coral communities across the central Great Barrier Reef. Coral Reefs 1: 95-107

Edmunds PJ (2005) The effect of sub-lethal increases in temperature on the growth and population trajectories of three scleractinian corals on the southern Great Barrier Reef. Oecologia 146:350-364

> Edmunds PJ (2010) Population biology of Porites astreoides and Diploria strigosa on a shallow Caribbean reef. Mar Ecol Prog Ser 418:87-104

Elahi R, Edmunds PJ (2007) Determinate growth and the scaling of photosynthetic energy intake in the solitary coral Fungia concinna (Verrill). J Exp Mar Biol Ecol 349: 183-193

Falkowski PG, Raven JA (2007) Aquatic photosynthesis, 2nd edn. Princeton University Press, Princeton, NJ

Farrell AP (2009) Environment, antecedents and climate change: lessons from the study of temperature physiology and river migration of salmonids. J Exp Biol 212: 3771-3780

Fulton C, Bellwood DR (2005) Wave-induced water motion and the functional implications for coral reef fish assemblages. Limnol Oceanogr 50:255-264

Gillooly JF, Brown JH, West GB, Savage VM, Charnov EL (2001) Effects of size and temperature on metabolic rate. Science 293:2248-2251

Gnaiger E (1983) Appendix C: Calculation of energetic and biochemical equivalents of respiratory oxygen consumption. In: Gnaiger E, Forstner R (eds) Polarographic oxygen sensors. Springer-Verlag, Berlin, p 337-345

> Hoegh-Guldberg O (1999) Climate change, coral bleaching and the future of the world's coral reefs. Mar Freshw Res 50:839-866

> Hoogenboom MO, Connolly SR (2009) Defining fundamental niche dimensions of corals: synergistic effects of colony size, light and flow. Ecology 90:767-780

> Hoogenboom MO, Anthony KRN, Connolly SR (2006) Ener- getic cost of photoinhibition in corals. Mar Ecol Prog Ser 313:1-12

Hoogenboom MO, Connolly SR, Anthony KRN (2009) Effects of photoacclimation on the light niche of corals: a process-based approach. Mar Biol 156:2493-2503

Hooper D, Vitousek P (1997) The effects of plant composition and diversity on ecosystem processes. Science 277 : 1302-1305

Hubbard DK, Scaturo D (1985) Growth rates of 7 species of scleractinian corals from Cane Bay and Salt River, StCroix USA Virgin Islands. Bull Mar Sci 36:325-338

> Jackson JBC (1977) Competition on marine hard substrate: the adaptive significance of solitary and colonial strategies. Am Nat 111:743-767

- Jokiel PL, Morrisey JI (1986) Influence of size on primary production in the reef coral Pocillopora damicornis and the macroalga Acanthophora spicifera. Mar Biol 91: $15-26$

Jones A, Berkelmans R (2010) Potential costs of acclimatization to a warmer climate: growth of a reef coral with heattolerant vs. sensitive symbiont types. PLoS ONE 5:e10437

> Kim K, Lasker HR (1998) Allometry of resource capture in colonial cnidarians and constraints on modular growth. Funct Ecol 12:646-654

> Lapid ED, Chadwick NE (2006) Long-term effects of competition on coral growth and sweeper tentacle development. Mar Ecol Prog Ser 313:115-123

> Leibold MA (1995) The niche concept revisited: mechanistic models and community context. Ecology 76:1371-1382

> Lesser MP, Weis VM, Patterson MR, Jokiel PL (1994) Effects of morphology and water motion on carbon delivery and productivity in the reef coral, Pocillopora damicornis (Linnaeus): Diffusion barriers, inorganic carbon limitation and biochemical plasticity. J Exp Mar Biol Ecol 178: 153-179

Leuzinger S, Anthony KRN, Willis BL (2003) Reproductive energy investment in corals: scaling with module size. Oecologia 136:524-531

Loya Y, Sakai K, Yamazoto K, Nakano Y, Sambali H, van Woesik R (2001) Coral bleaching: the winners and the losers. Ecol Lett 4:122-131

> Marsh JA (1970) Primary productivity of reef-building calcareous red algae. Ecology 51:255-263

Marshall PA, Baird AH (2000) Bleaching of corals in the GBR: differential susceptibilities among taxa. Coral Reefs 19:155-163

McClanahan TR, Ateweberhan M, Sebastian CR, Graham NAJ, Wilson SK, Bruggemann JH, Guillaume MMM (2007) Predictability of coral bleaching from synoptic satellite and in situ temperature observations. Coral Reefs 26:695-701

Nakamura T, van Woesik R (2001) Water-flow rates and passive diffusion partially explain differential survival of corals during the 1998 bleaching event. Mar Ecol Prog Ser 212:301-304

Oku H, Yamashiro H, Onaga K, Sakai K, Iwasaki H (2003) Seasonal changes in the content and composition of lipids in the coral Goniastrea aspera. Coral Reefs 22: 83-85

Rex A, Montebon F, Yap HT (1995) Metabolic responses of the scleractinian coral Porites cylindrica Dana to water motion. I. Oxygen flux studies. J Exp Mar Biol Ecol 186: $33-52$

> Rinkevich B (1996) Do reproduction and regeneration in damaged corals compete for energy allocation? Mar Ecol 
Prog Ser 143:297-302

Rinkevich B, Loya Y (1985) Intraspecific competition in a reef coral: effects on growth and reproduction. Oecologia 66:100-105

Sammarco PW, Coll JC, La Barre SC (1985) Competitive strategies of soft corals (Coelenterata: Octocorallia). II. Variable defensive responses and susceptibility to scleractinian corals. J Exp Mar Biol Ecol 91:199-215

Sebens KP, Helmuth B, Carrington E, Agius B (2003) Effects of water flow on growth and energetics of the scleractinian coral Agaricia tenuifolia in Belize. Coral Reefs 22: $35-47$

Tanner JE (2001) The influence of clonality on demography: patterns in expected longevity and survivorship. Ecology

Editorial responsibility: Peter Edmunds, Northridge, California, USA
82:1971-1981

Veron JEN (2000) Corals of the world. Australian Institute of Marine Science, Townsville

Villinski JT (2003) Depth-independent reproductive characteristics from the Carribean reef-building coral Montastrea faveolata. Mar Biol 142:1043-1053

- Ward S (1995) The effect of damage on the growth, reproduction and storage of lipids in the scleractinian coral Pocillopora damicornis (Linnaeus). J Exp Mar Biol Ecol 187:193-206

Weis VM, Allemand D (2009) What determines coral health? Science 324:1153-1155

Zar JH (1999) Biostatistical analysis, 4th edition. PrenticeHall, Upper Saddle River, NJ

Submitted: February 21, 2011; Accepted: June 22, 2011

Proofs received from author(s): September 26, 2011 